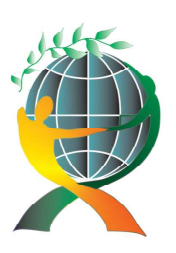

\author{
(online) $=$ ISSN $2285-3642$ \\ ISSN-L = $2285-3642$ \\ Journal of Economic Development, Environment and People \\ Volume 6, Issue 2, 2017 \\ URL: $\underline{\text { http://jedep.spiruharet.ro }}$ \\ e-mail: office jedep@spiruharet.ro
}

\title{
Theories Regarding the Role of the Growth Poles in the European Economic Integration
}

\author{
Laurenția Georgeta Avram ${ }^{1}$, Viorica Filofteia Bragă \\ ${ }^{1,2}$ SpiruHaret University, Faculty of Economic Sciences, Câmpulung Muscel, Romania
}

\begin{abstract}
The specialized literature stressed scarcely the role of the growth poles in the economic integration, although the development of the national economies depend on connecting the major urban centers in the regional economic system, continental and global levels. Conversely, integration and globalization of the economic, socio-political, cultural and the transition to a knowledge economy seem to be major factors in the transformation and restructuring of the growth poles and the urban systems dependent on them.
\end{abstract}

Keywords: Growth poles: economics, growth poles, economic integration, multi-polarity, regional integration

JEL Codes: F00

\section{Introduction}

Until now, the experts in Economics were unanimous in assessing the role of the growth poles in the economic development. The growth poles are considered the most dynamic elements of the economic growth, being the real locomotive of integration on the multiple levels: economic, technological, ideological, moral and spiritual in the development at the regional, continental and global levels.

If the growth poles achieved their integrative vocation as best as possible and implementing innovatively the collaborative networks in a polycentric territory, then they create conditions that allow people to use better valences of the economic integration for developing of those areas. Also, the growth poles use the integrative cooperation between respective integrative areas and among the small and medium-sized towns, both at internal borders and beyond the external borders of the respective integrative area.

When the emitted theories mainly by economists and sociologists, in the theory of the first, second and third generation and based on them, are grouped together, the study demonstrates the postulate that economic growth poles stimulates and potentiates the economic integration in those areas, constituting the true centre of economic integration alongside the free economic zones. 


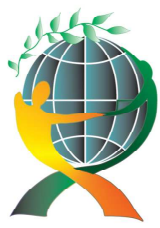

\author{
(online) $=$ ISSN $2285-3642$ \\ ISSN-L = $2285-3642$ \\ Journal of Economic Development, Environment and People \\ Volume 6, Issue2, 2017 \\ URL: $\underline{\text { http://jedep.spiruharet.ro }}$ \\ e-mail: office jedep@spiruharet.ro
}

\title{
2. Theories of the first generation
}

Johan Henrich von Thünen is considered the founder of the theory of the activities location, who, through his work, published in 1826, studied the location of the agricultural crops depending on the production costs and the distance to the market. Von Thünen's theory examines the allocation of the agricultural land among the multiple competitors' growth poles, considering that the agricultural product must be transported from the place of production to that of consumption.

Followers of the theory of Wilhelm von Thünen were: Wilhelm Launhardt, considered a pioneer of mathematical economics, and Alfred Weber, underlying the theory of location publishing in 1909 his "Theory of industrial location". Main interest of Weber was to define the location of the industrial enterprises on the mathematical basis regardless of their activity profile, switching from the microeconomic limited framework of a single company to a mezzo economic framework offering clues on the locations of areas of activity (economic branches).

\section{Theories of the second generation}

Theory of location was enhanced by other important contributions made by the German Wilhelm Roscher, the Englishman Ernest Ross and the Italian AchilleLoria. They focused on studying the role of the profit on the production process with the lowest cost in an industrial factory. Then Mark Blaug showed that the theory of the location failed to assert it in the mainstream of economics, being absorbed by socalled the regional science. Currently a special place in the location field of the industrial activity is occupied by the corporate behaviour study that demonstrated their tendency to group in space as clusters like the industrial parks, small or large cities etc.

In his article „La notion de pole de croissance”, François Perroux developed the theory of unbalanced growth of sectors or regions, known as polarized development theory or theory of the growth poles ${ }^{1}$. The theory begins from the fact that development is simultaneously an unbalanced and hierarchical process and that only certain business units act as engine of development. These units are designed poles of economic growth. The growth poles can become parts of territory or infrastructure. In the free market economy, there are relied on the spontaneous attenuation of gaps because of progress wave generated by the growth poles. Diffusion of the economic phenomena can sometimes lead to increase the gaps as the assimilative capacity of the wave of progress is higher in the centres of the growth poles, giving rise to other innovations that will strengthen the position of the growth poles. In addition, there are occurred the filter processes of the development broadcast activities, whereby more developed regions retaining the positive economic elements, dissipating the inconveniences towards the periphery.

John Friedmann, Stuart Holland and Gunnar Myrdal have created so-called theories of uneven development in the centre-periphery relationship stressing that regional imbalances are based on the chronological gaps that appear inherent in the integration processes, the gaps that result in the imperfect mobility of production factors.

\footnotetext{
${ }^{1}$ Francois Perroux, (1982, pp.307-320) Dialogue des monopoles et des nations: équilibre ou dynamique des unités actives? Grenoble, Presses Universitaires de Grenoble, (selective)
} 


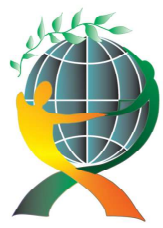

\author{
(online) $=$ ISSN $2285-3642$ \\ ISSN-L = $2285-3642$ \\ Journal of Economic Development, Environment and People \\ Volume 6, Issue 2, 2017 \\ URL: http://jedep.spiruharet.ro \\ e-mail: office jedep@spiruharet.ro
}

In Romania, the concerns studying the problems of the regional integration dates to the early part of the twentieth century, especially after 1925, when the sociologist Dimitrie Gusti, the Bucharest Monographic School founder, has created and coordinated multidisciplinary team of specialists who drafted after thorough field research, the impressive rural monographs; the villages and settlements analyzed, being at that time, the real growth poles for respective rural areas. Very interesting to underline is that Gusti drafted one of the first studies on the phenomenon entitled the United States of Europe. The method of the sociological monograph proved that the results obtained from the field investigations may underpin the design of some viable development programs of the growth poles that were studied rural communities.

In the 80s of the last century, Paul Nijkamp and Jean Paelinick focused on the theory of long cycles of the regional development, proposing the model of the interregional fluctuations, whereby the space is partitioned between growth poles, poles of attraction and intermediate regions. "The economic attractiveness" of an integrative region depends on the capital, infrastructure and stock information owned by that geographical area. In turn, the capital is generated by the performed investments and by the condition of the economic factors in that integrative area.

In our country, Ion Blaga, an economist, elaborates his work "The territorial distribution of the productive forces in Romania". His contribution stresses that rational territorial distribution of the productive forces is required to solve simultaneously two problems: the economic efficiency and the population growth as well as its judicious distribution in the territory. The author supports the idea of the balanced development of the counties to stop the migration from less developed counties to wealthy counties, especially towards the larger towns, making it difficult to solve the economic and social future raising problem of the lagging areas.

In 1993, the Swiss D. Maillat, M. Quévit and L. Senn analyses the growth poles constituted in the innovation networks and their effects ${ }^{2}$. In 1994, the Canadian B. Vachon refers to the partners' synergy in the local economic development, theorizing the relationship between entrepreneurship and the local production systems ${ }^{3}$. Then, in 1996, the French C. Fourcade and G. Garofoli talking about small companies' access to the technologies adapted for development, with emphasis on the role of the localized productive systems, respectively on the diffuse industrialization and local production systems - a difficult model to transfer to the developing countries; also in 1994 for the first time since our knowledge is presented by G. Paquet, Y. Belanger and A. Gaganon the Quebecois model of economic development ${ }^{4}$. Quebec can be considered as a growth pole model. After only two years, in 1996, the growth pole

\footnotetext{
${ }^{2}$ Maillat, D., Quévit, M. et Senn L., (1993, pp.1-13) Réseaux d'innovation et milieu innovateurs, in Maillat, D., Quévit M. and Senn, L. (coordinator), Réseauxd' innovation et milieu innovateurs: un pari pour le développement régional, Neuchâtel, EDES,(selective)

${ }^{3}$ Vachon, B., (1994, pp. 191-219) La synergie des partenaire sen développement économique local: entrepreneurship et systems productifs locaux, in M. U. Proulx (coordinator), Développement économique: clé de l'autonomie locale, Montréal, Les Éditions Transcontinental / Fondation de l'Entrepreneurship, (selective)

${ }^{4}$ Paquet, G., (1994, pp.22-28) Québec Inc: Mythe set réalités, in Y. Belanger et A. Gaganon (coordinator), Québec Inc: la dérive d'un modèle? Le modèle québécois de développement économique, Montréal: Éditions Québec-Amérique, (selective)
} 


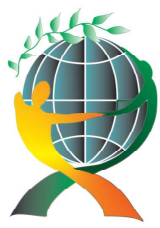

\author{
(online) $=$ ISSN $2285-3642$ \\ ISSN-L = $2285-3642$ \\ Journal of Economic Development, Environment and People \\ Volume 6, Issue2, 2017 \\ URL: http://jedep.spiruharet.ro \\ e-mail: office jedep@spiruharet.ro
}

represented by the Canadian Quebec conurbation is analysed as the core model of specific economic integration $^{5}$.

In 1998, the Frenchman Leon Alain analyses the phenomenon of multi polarization global economy, quoting here the poles of North American, European and Chinese in opposition to the marginalization of African pole, marked by the weakness of the interregional exchanges, by the insufficient development of the internal markets and by the weak diversification of the agricultural and industrial phenomenon ${ }^{6}$. The theory of polarization refers specifically at the interregional transfer phenomena and those of the regional or trans-regional feedback.

In addition, there are the specific integration phenomenon manifested in the most countries in Asia, characterized by the early public policy, the existence of commercial and financial regional networks, the quick accumulation of the financial and human capital, the sectoral changes of capitalist production, and opening of these markets to the economy world.

In the last decade of the 20th century, first in the association perspective and then the integration of Romania into the European structures, there were concerns for drawing up studies on integrated regional development based on the growth poles. Such studies were realised by the economic and sociological research institutes of the Romanian Academy, by the members of faculties and departments of ASE Bucharest and other universities from Bucharest and other important cities by the European Institute of Romania, under the auspices of EU funds and grants approved (by the World Bank, Switzerland, Liechtenstein and Norway etc.). Thus, under a PHARE program, the appointed councillors by the European Union together with representatives of the Romanian Government ministries have prepared in 1997 a set of important principles for regional development of our country.

\title{
4. Theories of the third generation
}

These theories come to complete the harmonious mode on the first two generations above. Theories of the third generation refers specifically to the cores of economic growth, existing both in the developed capitalist countries and in the developing ones (so-called emerging countries) or in underdeveloped countries.

It seems that Quebec pole of growth and economic integration has caused the liveliest analyses of specialists: In 2001, M.U. Proulx, analyses the "tectonic" of Quebecoise territories", then in 2003, M. Polèse and R. Shearrnur resume the concept of the development pole closely with the economic development strategies implemented in the Quebecois region ${ }^{8}$. Then, in 2005, the Brazilian J. Ferrera de Lima, draws some considerations on the growth poles and territorial strategies in Québec ${ }^{9}$. Analysis of the

\footnotetext{
${ }^{5}$ Hamel, P. et Klein, L., (1996, pp.293 -296)Le développement régional au Québec: enjeu de pouvoir et discours politique, in M. U. Proulx (coordinator), Le phénomène régional au Québec, Québec, PUQ, (selective)

${ }^{6}$ Alain, Leon, (1998, pp 623-645) Poles de croissance regionaux et integration mondiale: Afrique australe / aire economique chinoise, in Tiers Monde, vol. 39, (selective)

7 Proulx, M. U., (2001, pp.15-22) La tectonique des territoires québécois: Sommaireexécutif, Québec, Centre Québécois de Recherche et de Développement des Territoires (CQRDT), (selective)

${ }^{8}$ Polèse, M. et Shearrnur, R., (2003, pp.34-37), À propos du concept de pôle de développement et des stratégies de développement économique des régions québécoises, Hartmann Publishing House, (selective)

${ }^{9}$ Ferrera de Lima, J., (2005, pp. 161-171), Notes sur les pôles de croissance et les strategies territoriales au Québec, in Canadian Journal of Regional Science / Revue canadienne des sciences régionales, no. 1, (selective)
} 


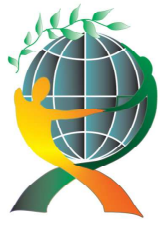

\author{
(online) $=$ ISSN $2285-3642$ \\ ISSN-L = $2285-3642$ \\ Journal of Economic Development, Environment and People \\ Volume 6, Issue 2, 2017
}

URL: http://jedep.spiruharet.ro

e-mail: office jedep@spiruharet.ro

Quebec experience demonstrates that the structure for occupying the space and the territorial strategies are mainly based on the demographic issues. According to the executive summary of polarization theory, developed by François Perroux (in his studies in 1955 and 1982, already quoted), the essence of the theory of economic development is limited to three postulates, which have, according to this thinking no relation to the economic integration: 1 . Growth is located, not disseminated in space or in the productive system; 2 . Economic growth is always in the imbalance. It has a variable intensity and transmitted along all the various channels with different effects for the whole economy in question; 3 . The existence of driving units or assembly of driving units, which takes related effect on other activities distributed in the same geographic area. We ask ourselves why a thinker as François Perroux did not see the link between growth poles and the phenomenon of economic integration, but instead he refers to the integration of the people into the labour market ${ }^{10}$.

Two Frenchmen Gervasio Semedo and Laurent Gautier and the Algerian Kamel Malik Bensafta described in 2012 the integrating European experience beginning with creating a single market and until to sign the Treaty of Maastricht, the three researchers highlight the political pragmatism and adopting the transparent rules are ways to reduce the structural fractures between countries ${ }^{11}$. However, EU enlargement with new members, the relaxation of budgetary discipline, asymmetry of countries to the shocks, the pressure of the markets, the differentiated budgetary policies of the EU countries showed that without a clear direction in coordination of the economic policy and a single currency can bring limits of the economic and monetary integration process.

Based on the rules of the Maastricht Treaty and the theory of optimum currency areas, combined and applied to the growth poles, three specialists have built a grid for analysing the structural heterogeneities countries belonging to the Economic Community of West Africa (CEAV). According to this grid, there were identified homogeneous sub-groups across countries wishing to form a monetary union or to constitute in a real pole of convergence. In the perspective of monetary integration, these poles can, first, be based the payment and clearing agreements, and to extend the experience to applying a common currency in a monetary unification. Structural approaches between CEAV countries were determined by applying the grid analysis, their regrouping on the development similar zones to circulate a single currency. Gervasio Semedo, Laurent Gautier and Kamel Malik Bensafta proposed the economic policy recommendations for each of the identified growth poles.

Between the experiments orientated to relationship of the growth poles with the phenomenon of economic integration, we quote an example: "Integrated growth poles (PIC)" - a project of the Government of Madagascar, which has as main objective to support the economic growth on a broadened social basis for identified poles as a driving force of growth ${ }^{12}$. It is the first project of its kind that was implemented around the world with the World Bank support. The PIC originality lies in the multiplicity of issues that are approached beside the traditional mono sectoral projects. Also, PIC aims to create a favorable framework for the private sector development, construction and rehabilitation of the key infrastructure of the growth poles, strengthening the capacity of the local communities, given the social and environmental aspects.

\footnotetext{
${ }^{10}$ Ferrera de Lima, J., (2005) Notes sur les pôles de croissance et les strategies territoriales au Québec, in Canadian Journal of Regional Science / Revue canadienne des sciences régionales, no. 1, (selective)

${ }^{11}$ Semedo, Gervasio; Gautier, Laurent et Kamel Malik Bensafta, (2012, pp.37-85) Pôles de convergence, gains dynamiques de I'intégration économique et monétaire en Afrique de l'Ouest: une approche en termes declusters, in L'Actualitééconomique, vol.88, no.1, (selective)

${ }^{12}$ Le ProjetPôlesIntégrés de Croissance, on the www.pic.mg, 2013
} 


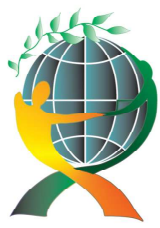

\author{
(online) $=$ ISSN $2285-3642$ \\ ISSN-L = $2285-3642$ \\ Journal of Economic Development, Environment and People \\ Volume 6, Issue2, 2017
}

URL: http://jedep.spiruharet.ro

e-mail: office jedep@spiruharet.ro

\title{
5. Multi-polarity - the new global economy
}

The growth poles on the emerging markets are reshaping the global economic structure ${ }^{13}$. In 2025 , more than half of the world growth will be concentrated in six large emerging economies (Brazil, China, India, Indonesia, South Korea and Russia), and the international monetary system will not still be dominated by a single currency, according the World Bank Report. On the new economic chessboard, these wealthy countries will contribute to the enhancing growth in the poor countries through trade and financial transboundary transactions. The group of six emerging countries will experience an average annual growth of $4.7 \%$ between 2011 and 2025. The growth forecast for industrialized countries, where the economic growth poles have long played their role integrator, are only $2.3 \%$ for the same period, but these countries will continue to dominate the global economy; thus, the Euro-zone, Japan, the United Kingdom and the United States remain the main engines of the global growth. "The rapid expansion of emerging countries has changed the distribution of the economic growth poles between developed countries and developing countries, creating a truly multipolar world" Justin Yifu Lin said, World Bank Chief Economist.

The report describes new challenges that will be revealed by the developing countries made over the next 20 years in a multipolar world economy. The authors used indicator based on empirical data to review countries with strong economic growth based on human capital and technological innovation. This increase will have a positive effect through trade, investment and cross-border migration will lead to the technology transfer and stimulate demand for export products. The report points out that many emerging countries could become growth poles such as China and South Korea - that rely heavily on exports or as Brazil and Mexico - which plays a big role in their consumption inside

Theory of unbalanced growth, theory of location and the theory of growth poles are examples of the first, second and the third generation who explained to the economic thought of those periods nineteenth century, the twentieth century, respectively, current century - the intrinsic relationship germs, biunique, between the poles of growth and economic integration.

These theories demonstrate the postulate which can better achieve through the growth poles the phenomenon of economic integration at the regional level, drawing on the best way the five freedoms of the specific movement of the integration phenomenon: economic goods (goods and services), workers, financial capital, a common currency and information. The network of urban development poles with the network of the growth poles forming urban polycentric systems that can counteract the negative spatial effects of the concentration and excessive economic development. Multi-polarity is the hallmark of the new world order.

Focusing the public investment in a limited number of towns has a strong impact on the development of the regional economies. Support of the network of the growth poles (rural and urban areas, by targeting a portion of the funds allocated by the local development to the poles in question, further strengthen their integrative position in the geography area, ensuring the integrated impact of the made investments. The growth poles can induce the rapid economic growth, to create jobs and boost labour productivity in the area. Thus, the phenomena of economic integration and cooperation are extended to small and medium towns and the adjacent rural areas, thus contributing to the integration and economic development of the entire region.

\footnotetext{
$13 * * *$ Global Development Horizons 2011-Multipolarity: The New Global Economy(Perspectives du développement mondial 2011 - Multipolarité: la nouvelle économie mondiale), Rapport de la Banque Mondiale, Washington, 17 May 2011; The full report, projections of the growth poles and other information can be found at: $\underline{w w w . w o r l d b a n k . o r g / g d h 2011}$
} 


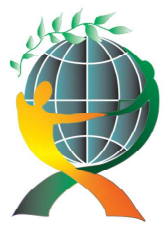

\author{
(online) $=$ ISSN $2285-3642$ \\ ISSN-L = $2285-3642$ \\ Journal of Economic Development, Environment and People \\ Volume 6, Issue 2, 2017
}

URL: http://jedep.spiruharet.ro

e-mail: office jedep@spiruharet.ro

\title{
6. Conclusions
}

Growth pole is a generator of economic activity, and its role is to amplify these activities. At the continental level or on the integrating large areas, the growth pole is a state, a country. Regionally a growth pole can be considered an economic activity, an industry or a settlement (urban or rural). At the microeconomic level we have proposed to consider the metropolitan urban area as a growth pole.

The engine of the regional diversification is provided by the technical progress, which maintains and activates the collaboration between different branches or activities, reducing the fluctuations in the economy at the region level.

Growth poles in the emerging markets are reshaping the global economic structure. In 2025, more than half of world growth will be concentrated in six large emerging economies (Brazil, China, India, Indonesia, South Korea and Russia), and the international monetary system will not be still dominated by a single currency, according to the World Bank Report. On the new economic chessboard, these wealthy countries will contribute to enhancing growth in the poor countries by the level of the commercial and financial cross-border transactions. The group of six emerging countries will have an average annual growth of $4.7 \%$ between 2011 and 2025. The growth forecast for the economically developed countries, in which the economic growth poles have long played their integrator role, are only $2.3 \%$ for the same period, but these countries will continue to dominate the global economy; thus, the Euro zone, Japan, the United Kingdom and the United States remain the main engines of the global growth. "The fast rise of emerging economies has driven a shift whereby the centres of economic growth are distributed across developed and developing economies - it's a truly multipolar world," said Justin Yifu Lin, the World Bank's chief economist.

We consider that in the next two or three decades, the global economy will experience changes of the growth poles level and polarization power and will grow larger and larger, predominantly generated by the economies of the emerging countries. While many high-income countries will recover only part from the financial crisis, the most developing countries will recover fast and will have a tendency to increase faster than before the crisis. Thus, China has already become the second economy in the world and recorded success after success. India is the second strong after China economically and financial-banking, and its government implement a new strategy for growth and sustainable development, with policies and better investment programs to maintain the economic growth. Brazil and Russia are new growth poles whose potential is currently intuited by the few specialists. Thus, it is expected to profoundly change the global balance of the economic power represented by the growth poles.

All these analyses highlight the expression of the sustainable growth with the prospect that enrolment growth pole on the path of the progress and civilization, at the levels of increasingly high, specific to the aspirations and expectations of the respectively people.

\section{References}

[1] Adams-Kane, J. \& Lim, J. J., 2011. Growth Poles and Multipolarity, in World Bank in Development Economics, Policy Research Working Papers

[2] Aldensi J., Boland P. (eds.), 1996. Regional Development Strategies: A European Perspective, Jessica Langley Eds., London

[3] Amerenne, Schoumaker, 1996. La localisation des industries, Nathan Press, Paris

[4] ***2014. Anuarul statistic al României 1990-2013, National Institute of Statistics, Bucharest,

[5] Perroux, F., 1982. Dialogue des monopoles et des nations: équilibre ou dynamique des unités actives? Grenoble, Presses Universitaires de Grenoble

[6] Pop, Napoleon; Fugaru, Amalia and Ioan Franc, Valeriu, 2010. Despre criză fără mânie și cu discernământ, Bucharest, Expert Publishing House 


\author{
(online) $=$ ISSN $2285-3642$ \\ ISSN-L = 2285 - 3642 \\ Journal of Economic Development, Environment and People \\ Volume 6, Issue2, 2017 \\ URL: http://jedep.spiruharet.ro \\ e-mail: office jedep@spiruharet.ro
}

[7] Proulx, M. U., 2001. La tectonique des territories qué bécois, Québec, Centre Québécois de Recherche et de Développement des Territoires,

[8] Vanhove, N., 1999. Regional Policy: A European Approach, third edition, Asgate,

[9] www.pic.mg

[10] www.worldbank.org/gdh2011 